\title{
Dekonstruksi Derrida terhadap Humanisme Barat
}

\author{
Chris Ruhupatty
}

(cruhupatty@gmail.com)

\begin{abstract}
This essay will present an analysis regarding how Jacques Derrida (1930-2004) deconstructed the Western's proposition about the properness of man under humanism. Through this essay, we also could find that deconstruction doesn't mean an act of reconstruction/restructuration of a proposition so we could have a better structure proposition compared to the previous one, or it doesn't mean an act of destruction/demolition of a proposition in order to change it to the new one. In fact, deconstruction is actually only an act of disclosure to a metaphysics of presence in the history of Western philosophy to indicate that the Western's tend to inaugurate a text to become a being that is present. Thus deconstruction in this essay will only disclose the veil of metaphysics of presence in the discourse about human under humanism without intending to reconstruct or destruct it.
\end{abstract}

Keywords: deconstruction, humanism, The Ends of Man, metaphysics of presence, telos.

\begin{abstract}
Abstrak: Tulisan ini menyajikan sebuah uraian tentang bagaimana Jacques Derrida (1930-2004) melakukan dekonstruksi terhadap proposisi filsafat Barat tentang hakikat manusia di bawah wacana humanisme. Melalui tulisan ini, kita juga dapat menemukan bahwa dekonstruksi tidak bermakna sebuah tindakan untuk merekonstruksi/memperbaiki struktur sebuah proposisi agar mendapatkan sebuah proposisi yang lebih baik dibandingkan sebelumnya, atau juga tidak bermakna sebuah tindakan untuk menghancurkan/merobohkan sebuah proposisi dengan tujuan untuk menggantikannya dengan sebuah proposisi yang baru. Faktanya, dekonstruksi sebenarnya hanya sebuah tindakan penyingkapan metafisika kehadiran di dalam sejarah filsafat Barat untuk menunjukkan bahwa filsafat Barat cenderung untuk menobatkan teks menjadi sebuah Kehadiran. Dengan demikian, dekonstruksi di dalam tulisan ini hanya akan menyingkapkan selubung metafisika kehadiran di dalam diskursus tentang manusia di bawah wacana humanisme tanpa bermaksud untuk memperbaiki atau menghancurkannya.
\end{abstract}


Kata-kata Kunci: dekonstruksi, humanisme Barat, The Ends of Man, metafisika kehadiran, telos.

Chris Ruhupatty lahir di Bogor, 8 September 1982. Saat ini berprofesi sebagai guru Pendidikan Agama Kristen di sebuah sekolah swasta di kota Bogor dan telah selesai menempuh studi filsafat di Program Magister STF Driyarkara, Jakarta.

\section{Pendahuluan}

Pertanyaan tentang "Siapakah manusia?" telah berusaha untuk ditemukan jawabannya sepanjang sejarah filsafat Barat di bawah wacana humanisme (selanjutnya dituliskan: humanisme Barat). Topik ini dibahas secara khusus oleh Derrida pada sebuah kolokium bertajuk "Philosophy and Anthropology" di New York, Oktober 1968. Makalah yang dibawakan oleh Derrida terbit setelahnya dengan judul The Ends of Man dalam Margins of Philosophy/MP (1972). Secara garis besar, The Ends of Man (TEM) berisikan dekonstruksi Derrida terhadap humanisme menurut pemikiran Prancis pasca-Perang Dunia II. Setelah selesai dengan humanisme Prancis, Derrida kemudian beralih kepada pemikiran tiga filsuf Jerman yang menjadi sumber inspirasi para pemikir Prancis dalam membangun humanismenya, yaitu GWF Hegel (1770-1831), Edmund Husserl (1859-1938), dan Martin Heidegger (1889-1976). Maka, secara keseluruhan TEM memiliki empat topik utama yang dibagi ke dalam lima subbahasan, yaitu (1) "Pengantar" yang tidak diberi judul oleh Derrida (MP, hlm. 111-114); (2) "Humanisme atau Metafisika" (MP, hlm. 114-117), berisikan dekonstruksi Derrida terhadap humanisme Prancis; (3) "Apa yang bisa dikatakan sebagai "manusia"” (MP, hlm. 117-119), berisikan uraian singkat Derrida mengenai pemikiran Hegel-Husserl-Heidegger; (4) "Mendekatnya tujuan akhir manusia (MP, hlm. 119123), di mana Derrida melakukan dekonstruksi terhadap Fenomenologi menurut Hegel dan Husserl; (5) Membaca kita (MP, hlm 123-136), berisikan dua topik: dekonstruksi Derrida terhadap pemikiran Heidegger dan penutup yang tidak diberikan subjudul oleh Derrida.

Artikel ini akan menjelaskan TEM dalam tiga subbahasan, yaitu (1) Humanisme Barat. Subbahasan ini memberikan sketsa sejarah perkembangan humanisme Barat untuk menjadi 
pengantar sebelum masuk pada uraian TEM. (2) Batas Akhir Pemikiran tentang Manusia. Subbahasan ini berisikan uraian TEM dengan fokus pada empat pemikiran yang menjadi topik utama. (3) Kesimpulan. Subbahasan ini memberikan penjelasan tentang "dekonstruksi sebagai sebuah penyingkapan terhadap selubung metafisika kehadiran" sekaligus menjelaskan mengapa Derrida tidak menawarkan sebuah proposisi untuk menjawab pertanyaan "Siapakah manusia?". Maka, jelas bahwa TEM tidak hanya menunjukkan posisi argumentasi Derrida terhadap humanisme Barat, tetapi juga memberikan penekanan terhadap permikirannya yang khas, yaitu dekonstruksi, yang membedakannya dengan pemikiran Prancis pasca-Perang Dunia II dan pemikiran Hegel-Husserl-Heidegger.

\section{Humanisme Barat}

Humanisme Barat secara resmi lahir sebagai sebuah diskursus tentang pencarian hakikat manusia pada permulaan era renaisans atau tepatnya abad ke-15 di Italia. Di awal kelahirannya, humanisme adalah sebuah kurikulum tentang manusia dengan nama studia humanitatis yang diampu oleh seorang umanista (humanis). Umanista sendiri merupakan sebutan bagi mereka yang mendalami studi literatur atau kesusastraan kuno yang berasal dari Yunani dan Romawi di era pra-Kristen. Dengan perkataan lain, studi tentang manusia ini adalah sebuah studi nonteologi ${ }^{1}$ meskipun corak teologi Kristiani masih melekat pada humanisme awal. Humanisme Barat sendiri baru benar-benar keluar dari pengaruh teologi Kristiani pada perkembangannya kemudian di abad ke-18.

Artikel ini akan menyajikan sketsa humanisme awal yang masih bercorak teologi Kristiani atau yang akan disebut sebagai "humanisme-teosentris" melalui dua tokohnya, yaitu Lorenzo Valla (1407-1447) dan Giovanni Pico Della Mirandola (1463-1494). Adapun humanisme sekular atau yang akan disebut sebagai "humanisme-antroposentris" akan disajikan melalui pemikiran dua tokoh yang cukup penting dalam memahami "keterpisahan" ini, yaitu Immanuel Kant (17241804) dan Ludwig Feuerbach (1804-1872).

\footnotetext{
${ }^{1}$ Andre Copson, "What is Humanism?" dalam The Wiley Blackwell Handbook of Humanism, editor Andrew Copson dan A.C. Grayling (West Sussex: John Wiley \& Sons, Ltd., 2015), hlm.1.
} 


\section{Humanisme-teosentris}

Lorenzo Valla dalam usahanya untuk menemukan hakikat manusia menghubungkan keberadaan manusia dengan keberadaan Tuhan secara total. Dalam hal ini Valla telah menempatkan Tuhan sebagai pusat atau tepatnya Pengatur-Tunggal dari seluruh keberadaan manusia. Maka, dalam pemikiran Valla, manusia dalam seluruh keberadaannya bertumpu secara total kepada Tuhan yang berpartisipasi langsung dalam setiap peristiwa yang terjadi dalam hidup manusia, baik di masa lalu, saat ini, maupun masa depan. Bahkan, Tuhan juga turut campur dalam hal-hal yang lebih spesifik, seperti penentuan bentuk dan warna. ${ }^{2}$

Valla menyebut Tuhan sebagai De vero bono (Kebaikan Sejati) yang memiliki sekurangkurangnya dua peran, yaitu sebagai kausalitas dan tujuan akhir dari seluruh keberadaan manusia. ${ }^{3}$ Sebagai konsekuensi dari campur-tangan Tuhan secara total dalam kehidupan manusia, sesungguhnya, Valla telah meniadakan peran manusia untuk bertindak atas nama dirinya sendiri atau yang biasa disebut sebagai kehendak bebas. Alhasil, hakikat manusia dalam pemikiran Valla niscaya bercirikan teosentris dengan menunjukkan bahwa kehidupan manusia akan mencapai kepenuhannya atau kelayakannya (proper) hanya di dalam genggaman tangan Tuhan yang tidak lain adalah Sang Kebaikan Sejati bagi manusia.

Di waktu yang hampir bersamaan dengan Valla, seorang humanis bernama Pico Mirandola yang melalui karyanya berjudul Oration on the Dignity (1496, terbit secara anumerta) merumuskan sebuah kajian tentang hakikat manusia yang berakar pada dogma Kristen tentang penciptaan dan kejatuhan manusia ke dalam dosa. Secara garis besar, Pico menyatakan bahwa hakikat manusia_yang disebutnya sebagai "martabat" (dignity)_adalah citra atau gambar Sang Pencipta yang diberikan saat Tuhan menciptakan manusia. Namun, manusia telah menjauh dari martabatnya sejak ia jatuh ke dalam dosa. ${ }^{4}$ Berangkat dari

\footnotetext{
2 John Monsofani, "The Theology of Lorenzo Valla" dalam Humanism and Early Modern Philosophy, editor Jill Kraye dan M.W.F. Stone (London dan New York: Routledge, 2000), hlm. 2.

${ }^{3}$ Ibid., hlm. 7.

${ }^{4}$ Bandingkan dengan Russell Kirk, "Introduction", dalam Oration on the Dignity of man, Penerj. A. Robert Caponigri (Chicago: Henry Regnery Company, 1956), hlm. xiii-xiv.
} 
doktrin penciptaan dan kejatuhan manusia menurut teologi Kristiani, Pico menghubungkan pengembangan diri manusia atau kelayakan manusia (proper of man) sebagai upaya untuk memulihkan martabatnya sebagai citra Allah yang kedudukannya lebih tinggi dibandingkan dengan ciptaan lainnya dan sedikit lebih rendah dari malaikat. ${ }^{5}$ Dengan demikian, Pico sebenarnya sedang menjelaskan bahwa manusia telah kehilangan martabatnya karena dosa dan jalan untuk memulihkan martabatnya itu adalah dengan kembali kepada Tuhan yang secara lugas ia sebutkan melalui pengembangan rasio dalam studi teologi dan filsafat. ${ }^{6}$ Namun, keputusan untuk mengambil jalan pemulihan tersebut tetap berada di tangan manusia sehingga Pico masih memberikan ruang bagi kehendak bebas manusia. Inilah yang membedakan antara pemikiran Valla dan Pico. Jika di dalam pemikiran Valla kita tidak dapat menemukan jawaban tentang adanya "kejahatan manusia," maka persoalan tersebut telah selesai di tangan Pico dalam konsep "kehendak bebas". Meskipun begitu, keduanya sepakat bahwa hakikat manusia ada di dalam hubungan antara manusia dan Tuhan. Maka, jelas bahwa pemikiran Pico tentang hakikat manusia tetap bercirikan teosentris.

2. Humanisme antroposentris

Pembicaraan tentang Tuhan telah mengalami sebuah pembaruan secara radikal di dalam pemikiran Kant jika dibandingkan dengan wacana humanisme-teosentris. Apabila Tuhan dalam wacana humanisme-teosentris dipahami sebagai Pribadi, di dalam wacana Kant kita tidak lagi menemukan Tuhan sebagai Pribadi, tetapi sebagai sebuah Idea yang tidak dapat dipahami tapi justru sangat dibutuhkan agar manusia dapat memahami realitas sebagai sebuah kesatuan yang utuh. ${ }^{7}$ Kant menyebutkan "Tuhan" bersama dengan "dunia" dan "jiwa" sebagai ide-ide regulatif (regulative ideas) yang menata kesadaran sehingga memungkinkan manusia untuk mendapatkan validitas yang obyektif terhadap seluruh realitas empiris. ${ }^{8}$ Dengan perkataan lain, realitas pada dirinya sendiri tidak dapat dipahami oleh manusia, tetapi dengan adanya ide-ide regulatif (Tuhan, dunia, dan jiwa) di dalam

${ }^{5}$ Giovanni Pico Della Mirandola, Oration on the Dignity of Man, Penerj. A Robert Caponigri (Chicago: Henry Regnery Company, 1956), hlm. 4.

${ }^{6}$ Ibid., hlm. 8-9.

${ }^{7}$ Lihat "Ideal", (2009), A Kant Dictionary. Editor Howard Caygill (Maden: Blackwell Publishing), hlm. 129-130.

${ }^{8}$ Lihat "Constitutive Principles", A Kant Dictionary, Editor Howard Caygill (Maden: Blackwell Publishing), hlm. 238-239. 
kesadaran manusia, manusia dapat melakukan konstruksi atau menata realitas sehingga dapat dikenali oleh logika.

Dengan demikian, jelas bahwa di dalam pemikiran Kant, Tuhan tidak lagi aktif berpartisipasi dalam kehidupan manusia. Untuk menjelaskannya, Kant menggunakan istilah Deistic yang berarti "Tuhan yang pasif" atau "Tuhan yang tidak mencampuri kehidupan manusia."9 Ilustrasi yang sering digunakan untuk memahami konsep Deistic menurut pemikiran Kant adalah ilustrasi "tukang arloji". Seorang tukang arloji telah menyelesaikan tugasnya setelah arloji yang dibuatnya bergerak sesuai dengan mekanisme yang ditentukan. Sama halnya dengan Tuhan. Tuhan telah menyelesaikan tugas-Nya sebagai Pencipta dan menyerahkan segala sesuatu berlangsung menurut hukum-hukum alam yang telah ditentukan.

Wacana Kant tentang Tuhan memiliki kemiripan dengan wacana René Descartes (15961650). Tuhan di dalam pemikiran Descartes berperan sangat penting dalam hal memberikan kemungkinan bagi manusia untuk memahami realitas secara obyektif. Dengan perkataan lain, jika seandainya Tuhan tidak mengendalikan pikiran manusia, maka manusia tidak dapat memiliki kebenaran yang obyektif. ${ }^{10}$ Maka, dapat dikatakan bahwa wacana Descartes tentang "aku yang berpikir"11 tidak mungkin terwujud tanpa campur tangan Tuhan. Namun, yang membedakan Descartes dan Kant dalam pembicaraan tentang "Tuhan" adalah dalam wacana Descartes, Tuhan masih dinyatakan sebagai Pribadi, sedangkan dalam Kant, Tuhan dianggap sebagai sebuah Idea.

\footnotetext{
${ }^{9}$ Immanuel Kant, Critique of Pure Reason, Penerj. Paul Guyer dan Allen W. Wood (Cambridge: Cambridge University Press, 1998), hlm. 608.

${ }^{10}$ Lihat "God". (2015). Historical Dictionary of Descartes and Cartesian Philosophy. Editor Roger Ariew, Dennis Des Chene, Douglas M. Jesseph, Tad M. Schmaltz, dan Theo Verbeek (Lanham: Rowman \& Littlefield), hlm. 162163.

${ }^{11}$ René Descartes, Discourse on the Method of Rightly Conducting the Reason, Penerj. Elizabeth S. Haldane dan G.R.T. Ross dalam Dover Philosophical Classics (New York: Dover Publications, Inc., 2003), hlm. 23.
} 
Klimaks dari pembicaraan tentang Tuhan dalam pemikiran Kant adalah ketika ia menggeser Tuhan sebagai pusat dari seluruh keberadaan manusia dan menggantikannya dengan manusia itu sendiri. ${ }^{12}$ Dengan menjadikan manusia sebagai pusat dan tujuan akhir bagi hidupnya, pemikiran Kant tentang manusia bercirikan antroposentris di mana hakikat manusia tidak ditemukan di luar dirinya, tetapi di dalam dirinya sendiri.

Wacana humanisme-antroposentris menjadi semakin matang di tangan Feuerbach dengan benar-benar mencoret Tuhan dalam pembicaraan tentang manusia. Wacana tersebut ia tuangkan melalui karyanya berjudul Das Wesen des Christentums (The Essence of Christianity) yang terbit pada 1841. Feuerbach beralasan bahwa ketika kita menjadikan Tuhan sebagai pusat dan tujuan akhir dari kehidupan manusia, yang terjadi adalah kita sedang merampas otentisitas dari sifat dan kualitas manusia itu sendiri. Hal tersebut mendorong dirinya untuk mengembangkan sebuah humanisme yang menjadikan sifat dan kualitas manusia itu sendiri sebagai dasar dari penemuan tentang hakikat atau kelayakan manusia (proper of man). ${ }^{13}$ Humanisme dalam pemikiran Feuerbach menjadi paripurna ketika ia mencoret Tuhan dengan menyatakan bahwa Tuhan tidak lain merupakan hasil proyeksi manusia belaka. Dengan tegas dan terinci Feuerbach menyebutkan kualitas-kualitas yang dimiliki Tuhan dan mengatakannya sebagai sebuah antitesis dari kualitas-kualitas yang dimiliki oleh manusia. Dengan kata lain, apa-apa yang dimiliki oleh Tuhan adalah keinginan atau cita-cita manusia yang tidak kesampaian. Sebagai contoh, Tuhan tidak-terbatas merupakan antitesis dari manusia yang terbatas; Tuhan yang sempurna merupakan antitesis dari manusia yang tidak sempurna; Tuhan yang abadi merupakan antitesis dari manusia yang fana; Tuhan yang Mahakuasa merupakan antitesis dari manusia yang lemah; Tuhan yang kudus merupakan antitesis dari manusia yang berdosa. Pendek kata, Tuhan adalah sisi positif dari seluruh sifat dan kualitas manusia, sedangkan manusia dengan segala keberadaannya adalah sisi negatif dari keberadaan Tuhan. ${ }^{14}$ Maka, Tuhan di mata Feuerbach adalah ciptaan

\footnotetext{
${ }^{12}$ Immanuel Kant, Critique of Practical Reason, hlm. 306.

13 Bandingkan dengan Rachel V. Kohout Lawrence, "Foreword", dalam The Essence of Christianity (Walnut: MSAC Philosophy Group, 2008), tanpa halaman.

${ }^{14}$ Ludwig Feuerbach, The Essence of Christianity, Penerj. Rachel V. Kohout Lawrence (Walnut: MSAC Philosophy Group, 2008), hal. 1.
} 
manusia dan ia juga telah menyatakan manusia sebagai Tuhan "sang pencipta". ${ }^{15}$ Alhasil, Feuerbach tidak hanya mengukuhkan wacana humanisme-antroposentris, tetapi juga membuka selubung antroposentrisme pada wacana humanisme-teosentris.

Feuerbach bukan yang pertama kali menyatakan Tuhan sebagai ciptaan manusia. Jauh sebelumnya, tepatnya di abad ke-5 SM, seorang filsuf Yunani bernama Xenophanes (570478 SM) menyatakan bahwa Tuhan adalah citra-manusia. ${ }^{16}$ Gagasan ini kontras dengan prinsip dasar humanisme-teosentris yang telah menyatakan manusia sebagai citra-Allah atau ciptaan Tuhan. Maka, jelas bahwa humanisme-antroposentris berusaha untuk menemukan hakikat manusia atau mengembangkan sifat dan kualitas manusia yang sejati di dalam diri manusia itu sendiri tanpa campur tangan Tuhan.

Dengan demikian, dapat disimpulkan bahwa humanisme menurut sejarah filsafat Barat merupakan sebuah wacana untuk menemukan hakikat manusia yang ditempuh melalui dua jalan, yaitu (1) menemukan hakikat manusia dalam hubungan antara manusia dan Tuhan di mana Tuhan dijadikan sebagai pusat dan tujuan akhir keberadaan manusia (teosentris) dan (2) menemukan hakikat manusia di dalam dirinya sendiri tanpa melibatkan Tuhan sehingga manusia dinyatakan sebagai pusat dan tujuan akhir dari seluruh keberadaannya (antroposentris).

Humanisme menurut sejarah filsafat Barat turut mewarnai peta peradaban dunia secara khusus dalam hal merumuskan hak asasi manusia (HAM). Perkembangan pemikiran filsafat Prancis pasca-Perang Dunia II juga tidak luput dari diskursus tentang manusia dan hakikatnya sebagai manusia. Bagaimana Prancis merumuskan humanismenya dan posisi argumentasi Derrida terhadapnya? Pertanyaan ini akan dijawab dalam subbahasan selanjutnya.

\footnotetext{
${ }^{15}$ Bandingkan dengan Ludwig Feuerbach, The Essence of Christianity, hal. 1.
}

${ }^{16}$ Bandingkan dengan Andrew Copson, What is Humanism, hal. 25. 


\section{Batas Akhir Pemikiran tentang Manusia}

"Batas akhir pemikiran tentang manusia" merupakan terjemahan dari The Ends of Man yang sudah diadaptasi sesuai pembacaan penulis. Sebagaimana telah disampaikan sebelumnya, topik utama TEM adalah dekonstruksi Derrida terhadap humanisme menurut pemikiran Prancis di era pasca-Perang Dunia II dan pemikiran-pemikiran yang turut membentuknya. Humanisme Prancis yang dimaksud di sini tentu saja "eksistensialisme" dan pemikiran-pemikiran yang membentuknya, yaitu pemikiran tiga filsuf asal Jerman: Hegel-Husserl-Heidegger. Topik-topik tersebut akan disarikan dalam tiga uraian berikut ini: (1) Humanisme Prancis: eksistensialisme sebagai humanisme, (2) Hegel-Husserl-Heidegger, dan (3) Kesimpulan.

1. Humanisme Prancis: eksistensialisme sebagai humanisme

Eksistensialisme berkembang pesat di Prancis sebagai sebuah humanisme dengan mengusung keunikan manusia sebagai individu ketimbang manusia sebagai sebuah entitas umum (universal) yang ditemukan pada proposisi humanisme Barat. ${ }^{17}$ Salah satu tokoh penting eksistensialisme yang menjadi fokus dalam uraian Derrida adalah Jean-Paul Sartre (1905-1980). Sartre memperkenalkan eksistensialisme sebagai sebuah humanisme melalui karya-karyanya, baik novel maupun esai, di antaranya Nausea (1938), Being and Nothingness (1943), dan Existentialism is a Humanism (1946).

Sartre melandasi humanismenya dengan menerjemahkan Dasein menurut pemikiran Heidegger sebagai "realitas-manusia."18 Dengan begitu, Sartre telah menjadikan Dasein sebagai manusia atau subyek sebagaimana manusia yang dibicarakan dalam wacana

\footnotetext{
${ }^{17}$ Bandingkan dengan "Existentialism", (1999), The Cambridge Dictionary of Philosophy: Second Edition. Editor Robert Audi (Cambridge: Cambridge University Press), hlm. 296.

18 Jacques Derrida, Margins of Philosophy, Penerj. Alan Bass (Sussex: The Harvester Press Limited, 1982), hlm.115.
} 
humanisme Barat. Padahal, Heidegger sendiri telah membedakan Dasein dan manusia dalam humanisme Barat untuk menunjukkan bahwa Dasein tidak dapat didefinisikan oleh apa pun juga. ${ }^{19}$ Meskipun "realitas-manusia" dalam pemikiran Sartre memiliki kebebasan secara penuh untuk mendefinisikan dirinya sendiri, ${ }^{20}$ tetap saja "realitas-manusia" adalah manusia atau subyek yang menyatu dengan definisinya atau hakikatnya sebagai manusia. Maka, di mata Derrida, Sartre dianggap tidak memahami prinsip dasar dari humanisme Barat, yaitu menemukan hakikat manusia yang membawa pada penyatuan antara manusia dan hakikatnya. Sartre juga dianggap tidak memahami prinsip dasar dari pemikiran Heidegger yang berusaha untuk membawa pembicaraan tentang manusia keluar dari pencarian hakikatnya yang membawa pada adanya jarak antara manusia dan hakikatnya (Being). ${ }^{21}$

Dengan demikian, jelas bahwa di mata Derrida, humanisme menurut pemikiran Sartre memiliki prinsip yang sama dengan humanisme Barat dan humanisme menurut doktrin Kristiani, yaitu menjadikan penyatuan antara manusia dan hakikatnya (Being) sebagai tujuan akhir dari seluruh keberadaan manusia. ${ }^{22}$ Walaupun "hakikat" (Being) dalam pemikiran Sartre dinyatakan sebagai sebuah Ketiadaan (nothingness), ${ }^{23}$ prinsip dasarnya tetap sama, yaitu penyatuan antara manusia dan hakikatnya (Being). Alhasil, Sartre telah jatuh ke dalam jerat metafisika kehadiran yang sama dengan humanisme Barat dengan ciri menjadikan hakikat manusia sebagai sebuah entitas (Being) yang hadir di luar teks. Seolah-olah hakikat manusia telah hadir sebelum manusia konkret sehingga keberadaan manusia konkret terisap untuk menjadi sama dengan hakikatnya. Jerat metafisika inilah yang berusaha dihindari oleh Heidegger. Karena itu, Heidegger menegaskan bahwa: "semua humanisme adalah metafisika." 24

Dengan demikian, humanisme Prancis atau yang dikenal sebagai eksistensialisme merupakan hasil dari kekeliruan para pemikir Prancis, khususnya Sartre, dalam hal

\footnotetext{
19 Bandingkan dengan "Dasein” (1999), The Blackwell Philosopher Dictionaries: A Heidegger Dictionary, Editor Michael Inwood (Oxford: Blackwell Publishers Ltd), hlm, 42-44.

${ }^{20}$ Bandingkan dengan Jean-Paul Sartre, Being and Nothingness: An Essay on Phenomenological Ontology, Penerj. Hazel Barnes (New York: Philosophical Library,1956), hlm. 17.

${ }^{21}$ Jacques Derrida, Margins of Philosophy, hlm.115-6.

22 Jacques Derrida, Margins of Philosophy, hlm.116.

${ }^{23}$ Jean-Paul Sartre, Being and Nothingness: An Essay on Phenomenological Ontology, hlm. 16.

${ }^{24}$ Jacques Derrida, Margins of Philosophy, hlm.116.
} 
membaca karya-karya Heidegger dengan menggunakan sudut pandang humanisme. Bahkan, kekeliruan tersebut tidak hanya terhadap karya-karya Heidegger, tetapi juga pada karyakarya Hegel dan Husserl. Setidaknya hal itu tampak pada penggunaan istilah "Being-foritself" dan "fenomenologi” (lihat Being and Nothingness: An Essay on Phenomenological Ontology). Karena itu, setelah selesai melakukan dekonstruksi terhadap humanisme Prancis, Derrida beralih pada pemikiran Hegel-Husserl-Heidegger untuk menjelaskan kekeliruan yang dilakukan oleh para pemikir Prancis tersebut. Pemikiran Hegel-Husserl-Heidegger bukanlah sebuah humanisme dalam arti melakukan penghancuran terhadap proposisi humanisme Barat demi menggantikannya dengan sebuah humanisme baru seperti yang dilakukan oleh Sartre. Justru Hegel-Husserl-Heidegger ingin membawa pembicaraan tentang manusia keluar dari jerat untuk mencari hakikat manusia yang membawa kepada penyatuan antara manusia dan hakikatnya (Being). Maka, yang dilakukan oleh ketiganya adalah memperbaiki proposisi humanisme. Hasil dari perbaikan tersebut adalah pemikiran dari masing-masing filsuf tersebut. Dengan perkataan lain, ketiganya memperbaiki atau melakukan rekonstruksi terhadap proposisi humanisme Barat tanpa menggantikannya dengan sebuah proposisi baru dengan tanda bahwa masing-masing tidak menjadikan pemikirannya sebagai sebuah humanisme. Maka, jelas bahwa pemikiran Hegel-HusserlHeidegger sebenarnya masih berada pada cakrawala humanisme, tetapi ketiganya tidak menyebutkannya secara terbuka. ${ }^{25}$ Perbedaan sikap antara Hegel-Husserl-Heidegger dan Sartre inilah yang hendak dijelaskan oleh Derrida melalui TEM.

\section{Hegel-Husserl-Heidegger}

Pemikiran ketiga filsuf asal Jerman ini berangkat dari kritik atas humanisme Barat tanpa menjadikan pemikiran masing-masing sebagai sebuah humanisme baru untuk menggantikan yang lama. Sebut saja Hegel yang secara gamblang memisahkan topik pembahasan tentang antropologi dan fenomenologi roh dalam uraiannya yang berjudul Mind Subjective, ${ }^{26}$ atau Husserl yang dengan tegas memberikan perbedaan antara "manusia" yang dimaksudkan

\footnotetext{
${ }^{25}$ Jacques Derrida, Margins of Philosophy, hlm.116.

${ }^{26}$ Lihat Georg Wilhelm Friedrich Hegel, "Section I. Mind Subjective" dalam The Encyclopedia of the Philosophical Sciences Volume 3: Hegel's Philosophy of Mind, Penerj. W. Wallace dan A.Y. Miller Revisi oleh Michael Inwood (Oxford: Clendon Press, 2012).
} 
dalam pemikirannya berbeda dan "manusia" yang ditemukan dalam proposisi humanisme Barat. Jika "manusia" dalam humanisme Barat selalu dikaitkan dengan masyarakat, budaya, bahasa, dan kesadaran atau jiwa (psyche), maka "manusia" yang dimaksudkan oleh Husserl adalah manusia yang dikaitkan dengan sebuah kesadaran tanpa jiwa (Jerman: seelenlos) atau dengan kata lain sebuah kesadaran tanpa manusia. ${ }^{27}$ Adapun Heidegger merasa perlu untuk menerbitkan Letter on Humanism (1947) sebagai klarifikasi bahwa karyanya berjudul Sein und Zeit (1927) bukanlah sebuah humanisme karena yang menjadi topik utama dari seluruh uraiannya adalah "penghancuran secara positif" (Jerman: Destruktion) terhadap metafisika atau ontologi filsafat Barat. ${ }^{28}$ Namun, uraian Derrida tidak berhenti pada pembuktian bahwa pemikiran Hegel-Husserl-Heidegger bukanlah sebuah humanisme demi menjelaskan kekeliruan yang dilakukan oleh para pemikir Prancis. Ia justru melanjutkan uraiannya untuk membuktikan bahwa ketiganya telah melakukan rekonstruksi atau relève terhadap proposisi humanisme Barat. Dengan perkataan lain, Derrida membuktikan bahwa secara tertulis masing-masing filsuf menyatakan bahwa pemikiran mereka bukanlah sebuah humanisme, melainkan sesungguhnya ketiganya masih membicarakan tentang manusia. Manusia seperti apakah yang akan kita temukan dalam pemikiran Hegel-Husserl-Heidegger? ${ }^{29}$

\section{Hegel}

Derrida membuktikan bahwa Hegel mendasari pemikirannya tentang fnomenologi roh dengan melakukan relève atau aufhebung terhadap proposisi humanisme Barat, atau istilah lain, fenomenologi roh menurut pemikiran Hegel adalah sintesis dari proposisi humanisme Barat. Karena humanisme dalam pemikiran Hegel dinyatakan sebagai natur dari jiwamanusia (being-in-itself) yang masih tertidur atau tertutup pada dunia di luar dirinya, jiwamanusia dapat diumpamakan seperti "benih" atau "bahan mentah" dari sifat atau kualitas manusia. ${ }^{30}$ Adapun fenomenologi merujuk kepada natur dari kesadaran yang dikenal sebagai ego atau subyek yang tidak ditemukan pada jiwa-manusia yang disebutkan sebelumnya. ${ }^{31}$

${ }^{27}$ Jacques Derrida, Margins of Philosophy, hlm.117-8.

${ }^{28}$ Jacques Derrida, Margins of Philosophy, hlm.118.

${ }^{29}$ Jacques Derrida, Margins of Philosophy, hlm.118-9.

${ }^{30}$ Bandingkan dengan Georg Wilhelm Friedrich Hegel, "Section I. Mind Subjective" dalam The Encyclopedia of the Philosophical Sciences Volume 3: Hegel's Philosophy of Mind, Penerj. W. Wallace dan A.Y. Miller Revisi oleh Michael Inwood (Oxford: Clendon Press, 2012).

${ }^{31}$ Bandingkan dengan Glenn Alexander Magee dalam "[P]henomenology (die Phänomenologie)” (2010). The Hegel Dictionary, hlm. 167-8. 
Maka, jelas bahwa fenomenologi atau kesadaran merupakan sebuah sintesis atau hasil dari relève yang dilakukan oleh Hegel terhadap proposisi humanisme Barat. Dengan lain perkataan, Hegel hendak mengungkapkan bahwa kesadaran yang dibicarakan oleh humanisme adalah kesadaran-akan-diri atau kesadaran yang masih tertutup terhadap dunia di luar manusia. Hegel melakukan perbaikan atau relève terhadap kesadaran dalam wacana humanisme Barat dengan mengusung sebuah konsep tentang fenomenologi atau kesadaran di mana dunia dan diri dapat ditemukan di dalamnya. Alhasil, di mata Derrida, fenomenologi roh menurut pemikiran Hegel tetaplah sebuah wacana yang menjelaskan struktur atau hakikat dari kesadaran manusia. ${ }^{32}$

Fenomenologi roh menurut pemikiran Hegel, lanjut Derrida, juga mengungkapkan penyatuan antara akhir manusia (jiwa yang tertutup) di satu sisi dan pencapaian manusia (fenomenologi) di sisi lainnya. "Akhir manusia" menandakan keterbatasan dari jiwamanusia, sedangkan "pencapaian manusia" menandakan ketidak-terbatasannya, yaitu fenomenologi. Namun, di mata Derrida, pemikiran Hegel ini masih berada dalam jerat metafisika kehadiran karena Hegel telah menyatakan fenomenologi sebagai sebuah kehadiran yang lebih konkret daripada manusia itu sendiri. Itulah kenapa dalam pemikiran Hegel, penyatuan antara fenomenologi (entitas atau Being di luar manusia) dan manusia disebut sebagai kami (we). ${ }^{33}$

Dengan demikian, pemikiran Hegel masih berada pada cakrawala metafisika kehadiran yang sama dengan humanisme Barat yang sekurang-kurangnya ditandai dengan dua ciri yang sama, yaitu (1) mengusung ide tentang penyatuan antara manusia dan Being sebagai tujuan akhir sekaligus pencapaian manusia dan (2) menyatakan fenomenologi sebagai entitas (Being) yang lebih konkret daripada manusia yang ada dihadapan kita. Pendek kata, fenomenologi dan humanisme Barat memiliki struktur yang sama, yaitu sama-sama menatap manusia dalam kerangka tujuan akhir (telos). Di dalam kerangka yang bersifat teleologis

\footnotetext{
32 Jacques Derrida, Margins of Philosophy, hlm.120-1.

${ }^{33}$ Lihat juga catatan kaki no. 15 yang menjelaskan tentang "kami" (we) pada uraian Derrida dalam Jacques Derrida, Margins of Philosophy, hlm.121-2.
} 
inilah, makna (eidos) atau hakikat manusia ditemukan. Namun, pertanyaannya adalah apakah hakikat manusia lebih konkret dari manusia itu sendiri?

\section{Husserl}

Sebagaimana telah dijelaskan di atas bahwa struktur fenomenologi menurut pemikiran Hegel dibangun dalam kerangka pemikiran yang bersifat teleologi. Ternyata, ciri yang sama juga dapat ditemukan pada struktur fenomenologi menurut pemikiran Husserl. Bahkan, dalam pandangan Derrida, kerangka teleologi dari fenomenologi semakin kentara di tangan Husserl. Derrida menemukan kesamaan fungsi antara kerangka teleologi di dalam pemikiran Husserl dan ide-ide regulatif dalam pemikiran Kant atau rasio dalam pemikiran Descartes. Maka, jelas bahwa manusia yang dibicarakan oleh Husserl adalah manusia yang sama dengan yang dibicarakan oleh Kant, Descartes, dan humanisme Barat, yaitu manusia yang dikenal sebagai hewan-rasional (animal rationale). Namun, faktor pembeda antara Husserl dan yang lainnya adalah Husserl tidak menggunakan istilah "rasio" melainkan "sejarah" karena "rasio" dalam pemikiran Husserl_juga Hegel—adalah "sejarah." Kesadaran dalam pemikiran Husserl tidak ditemukan pada rasio manusia yang menyadari dirinya sendiri, tetapi pada intensionalitas atau kesadaran di dalam dunia. ${ }^{34}$

Dengan demikian, di mata Derrida, hakikat manusia dalam kerangka teleologi Husserl ditemukan dalam penyatuan antara "akhir manusia" atau kematian di satu sisi dan "sejarah" atau rasio-teleologis yang melintasi seluruh sejarah peradaban manusia di sisi lainnya. Alhasil, Husserl telah masuk pada jerat metafisika kehadiran yang sama dengan humanisme Barat dengan menyatakan "sejarah" yang melintasi peradaban manusia (abadi) sebagai entitas (Being) yang lebih konkret dari manusia itu sendiri. Dalam hal ini, lanjut Derrida, sebenarnya Husserl sedang melakukan relève terhadap proposisi humanisme Barat. Jika humanisme Barat menyatakan bahwa kesadaran manusia ditemukan di dalam rasio yang menyadari dirinya sendiri, maka bagi Husserl, kesadaran manusia ditemukan di dalam

34 Transcendental (transzendental). (2021). The Husserl Dictionary. Editor Dermot Moran dan Joseph Cohen (London: Continuum International Publishing Group), hal. 327-8. 
penyatuannya dengan sejarah (intensionalitas). ${ }^{35}$ Pendek kata, fenomenologi menurut pemikiran Husserl masih membicarakan manusia dalam cakrawala metafisika kehadiran yang sama dengan humanisme Barat.

\section{Heidegger}

Derrida mengakui kejelian Heidegger dalam melihat jerat metafisika kehadiran dalam pembicaraan tentang manusia dibandingkan dengan dua filsuf sebelumnya, khususnya dalam hal melihat "penyatuan antara manusia dan hakikatnya (Being)" sebagai wujud dari seluruh bangunan metafisika. Oleh sebab itu, kita tidak akan menemukan ide "penyatuan" tersebut dalam pemikiran Heidegger. Sebagai gantinya, kita akan menemukan apa yang disebut oleh Derrida sebagai "tarikan magnetik" atau "kedekatan" antara manusia dan hakikatnya (Being). Alhasil, di mata Derrida, Dasein menurut pemikiran Heidegger tidak dapat dengan begitu saja disebut sebagai manusia metafisis sebagaimana manusia dalam humanisme Barat. ${ }^{36}$ Namun, pertanyaannya adalah "kedekatan" seperti apakah yang dimaksud oleh Derrida?

Di mata Derrida, Heidegger paham betul bahwa pengetahuan kita tentang "hakikat" (Being) atau "adalah" (is) masih samar-samar. Kenyataan inilah yang coba diungkapkan oleh Heidegger melalui Being and Time dengan mengatakan, "Pertanyaan, sebagai bentuk dari sebuah pencarian pastilah membutuhkan panduan dari apa yang berusaha untuk dicari. Karena itu, pengartian mengenai Hakikat pastilah selalu sudah tersedia bagi kita melalui cara seperti itu. Sebagaimana yang telah kita nyatakan bahwa kita selalu sudah [cetak miring oleh Derrida] terjalin di dalam sebuah pengartian mengenai Hakikat. Melalui ini semua muncullah pertanyaan eksplisit mengenai pengartian Hakikat dan kecenderungan yang membawa kepada konsepnya. Kita tidak mengetahui apa itu 'Hakikat.' Namun, sesudah kita bertanya, 'Apa itu 'Hakikat'?' kita [cetak miring oleh Derrida] berada di sebuah pengartian mengenai 'adalah' tanpa mampu untuk menentukan secara konseptual apa itu 'adalah.' Kita

\footnotetext{
35 Jacques Derrida, Margins of Philosophy, hal.122-3.
}

${ }^{36}$ Jacques Derrida, Margins of Philosophy, hal.123-4. 
bahkan tidak mengetahui cakrawala di mana kita seharusnya memahami dan menjabarkan pengartiannya. Maka, pengartian kita yang samar-samar tentang Hakikat merupakan sebuah fakta yang tak terelakkan." ${ }^{37}$ Cetak miring oleh Derrida dalam kutipan ini hendak menunjukkan bahwa pengartian kita mengenai Hakikat (Being) niscaya dibatasi oleh sekurang-kurangnya dua hal, yaitu (1) Struktur pertanyaan atau pencarian yang merupakan panduan kepada halnya dan (2) Dibatasi oleh contoh Hakikat (Being) yang dapat ditangkap oleh indra atau dapat dikenali oleh logika. ${ }^{38}$ Maka, jelas bahwa pengartian kita terhadap hakikat manusia sebenarnya masih samar-samar. Karena pengartian tersebut dibatasi oleh apa yang dapat ditemui oleh indra dan dikenali logika saja, pengartian kita niscaya tidak mencakup hal-hal yang tidak dapat ditemui oleh indra dan dikenali oleh logika. Berangkat dari kenyataan tersebut, Heidegger mengajak kita untuk mempertanyakan kebenaran Hakikat (Being) dan melakukan "penghancuran secara positif" (destruktion) terhadap semua klaim atas penemuan hakikat realitas menurut sejarah filsafat Barat. Alhasil, kita tidak akan menemukan konsep "penyatuan" antara hal-nya dan hakikat-nya atau dalam konteks ini adalah penyatuan antara manusia dan hakikatnya karena ide "penyatuan" tersebut adalah sebuah kemustahilan. Paling banter hanyalah sebuah "kedekatan" atau "tarikan-magnetis" antara manusia dan apa yang disebutkan sebagai hakikatnya.

Hanya saja, di mata Derrida, meskipun "kedekatan" ini telah dirancang untuk meloloskan diri dari jerat metafisika kehadiran, tetap saja Heidegger masih berada di dalam jerat yang sama. Ditandai sejak Heidegger mengubah "kedekatan" yang mulanya bersifat ontic (faktual) menjadi ontologis. Sejak itulah Heidegger telah membawa pemikirannya tentang Dasein ke arah pembicaraan tentang hakikat manusia, yaitu kedekatan dengan Hakikat $(\text { Being) })^{39}$ sehingga seolah-olah "Kedekatan" merupakan entitas (Being) yang hadir di luar teks dan lebih konkret dari manusia. Pendek kata, pemikiran Heidegger masih merupakan pemikiran tentang manusia sebagaimana humanisme Barat. Namun, Heidegger telah melakukan perbaikan (relève) terhadap proposisi humanisme Barat dengan menunda

\footnotetext{
${ }^{37}$ Derrida mengutip Martin Heidegger, Being and Time, Penerj. John Macquarrie dan Edward Robinson (New York: Harper and Row, 1963), hlm. 25 dengan memberikan cetak miring. Jacques Derrida, Margins of Philosophy, hlm.124.

38 Jacques Derrida, Margins of Philosophy, hlm.125-6.

39 Jacques Derrida, Margins of Philosophy, hlm.126-133.
} 
penyatuan antara manusia dan hakikatnya. Artinya, manusia atau Dasein masih memiliki kebebasan untuk menentukan jati dirinya tanpa harus dibatasi oleh hakikatnya yang masih samar-samar itu. Untuk itulah, Heidegger juga dikenal sebagai salah satu pendiri eksistensialisme.

Oleh karena itu, lanjut Derrida, kita tidak perlu memikirkan "kedekatan" antara manusia dan hakikatnya karena pemikiran tentang Hakikat dengan sendirinya telah dibatasi oleh kefanaan tubuh manusia atau kematian. Namun, pemikiran tentang Hakikat seolah-olah hendak menjelaskan makna di balik kematian dalam permainan tujuan-akhir (telos) sehingga seolaholah kehidupan manusia memiliki makna meskipun kematian tidak dapat dihindari dan tidak dapat dipahami. Dengan perkataan lain, kematian manusia merupakan awal dari pemikiran tentang Hakikat dan secara bersamaan, kematian merupakan akhir dari pemikiran tentang Hakikat. ${ }^{40}$ Maka, jelas bahwa bukan hanya pengartian kita tentang Hakikat yang samarsamar, melainkan landasan dari pencarian Hakikat itu sendiri, yaitu kematian, juga merupakan realitas yang samar atau tidak dapat dipahami.

Derrida menutup seluruh uraiannya dengan memberikan kesimpulan bahwa seluruh bentuk humanisme terkondisikan bersifat metafisika. Hegel-Husserl-Heidegger dan Sartre berusaha untuk meloloskan diri dari jerat metafisika dalam pembicaraan tentang manusia, tetapi ternyata mereka pun masih berada di dalam cakrawala yang sama dengan humanisme Barat. Hegel-Husserl-Heidegger melakukan relève terhadap proposisi humanisme Barat dan masing-masing menghasilkan sebuah pemikiran filosofis yang pada akhirnya tetap mengusung sebuah esensi atau hakikat sebagai entitas (Being) yang hadir di luar teks dan kehadirannya lebih konkret dari manusia itu sendiri. Adapun Sartre telah menghancurkan proposisi humanisme Barat dan menggantikannya dengan eksistensialisme sebagai sebuah humanisme baru. Namun, Sartre masih berada dalam jerat metafisika yang sama dengan humanisme Barat karena tetap mengusung ide penyatuan antara manusia dan Hakikat-nya (Being). Meskipun "Hakikat" dalam pemikiran Sartre dinyatakan sebagai Ketiadaan, tetap

\footnotetext{
${ }^{40}$ Jacques Derrida, Margins of Philosophy, hlm.133-4.
} 
saja Ketiadaan tersebut telah dinyatakan sebagai sebuah kehadiran (Being) di luar teks yang bahkan lebih konkret dari manusia itu sendiri. Derrida sendiri tidak menolak setiap proposisi tentang manusia dan hakikatnya atau dengan istilah lain ia tidak anti terhadap humanisme. Ia hanya menyingkapkan selubung metafisika dalam pembicaraan tentang manusia tanpa berusaha untuk memperbaiki (relève) atau menghancurkan proposisi humanisme. Untuk itu, ia memilih untuk merengkuh seluruh proposisi tentang manusia dan hakikatnya tanpa menjadikan salah satunya sebagai sebuah Hakikat atau tujuan akhir dari seluruh keberadaan manusia karena di matanya, Hakikat manusia adalah sebuah permainan dari tujuan-akhir (telos) yang membuat seolah-olah keberadaan manusia memiliki makna. Selain itu, penemuan Hakikat manusia sekurang-kurangnya memiliki dua efek-samping, yaitu (1) dapat membatasi realisasi seluruh sifat dan kualitas manusia dan (2) akan mengalihkan pandangan manusia dari kematian dengan membuat seolah-olah kehidupan dan kematian itu sendiri memiliki makna karena adanya Hakikat yang dinyatakan sebagai tujuan-akhir sekaligus pencapaian tertinggi manusia. ${ }^{41}$

\section{Kesimpulan}

Telah jelas bahwa dekonstruksi Derrida terhadap proposisi humanisme Barat menunjukkan ciri khas dari pemikirannya yang berbeda dengan fenomenologi dan eksistensialisme. Dekonstruksi tidak merekonstruksi atau memperbaiki (relève) sebuah proposisi, apalagi menghancurkannya secara total demi membangun sebuah proposisi baru, tetapi sebuah penyingkapan terhadap jerat metafisika kehadiran dengan ciri menjadikan Hakikat sebagai sebuah kehadiran layaknya sebuah entitas (Being). Adapun bagi Derrida, tidak ada suatu apa pun yang hadir di luar teks (il n'y a pas de hors-texte ${ }^{42}$ sehingga dalam konteks pembicaraan tentang manusia, humanisme telah menobatkan hakikat manusia yang awalnya adalah teks semata menjadi sebuah kehadiran di luar teks, bahkan dinyatakan sebagai kehadiran yang lebih konkret dari manusia itu sendiri. Pendek kata, di mata Derrida, Hakikat manusia tidak lain adalah sebuah teks tentang manusia. Karena teks memiliki kemampuan

\footnotetext{
${ }^{41}$ Jacques Derrida, Margins of Philosophy, hlm.134-6.

42 Jacques Derrida, Of Grammatology, Penerj. Gayatri Chakravorty Spivak (Baltimore: The Johns Hopkins University Press, 1997), hal. 158.
} 
untuk dibaca dan dituliskan ulang secara lain (iterability), ${ }^{43}$ Derrida merengkuh semua bentuk humanisme dan selalu menantikan bahkan mendorong kemunculan teks yang-lain (oto-dekonstruksi). Dengan demikian, jika ditanyakan kepada Derrida: "Siapakah manusia?", jawabnya adalah "Semua teks yang mengucapkan dan menuliskan tentang manusia."

\section{Penutup}

Pertanyaan tentang "Siapakah manusia?" merupakan sebuah pertanyaan yang berusaha untuk ditemukan jawabannya sepanjang sejarah peradaban manusia itu sendiri. Namun, Derrida dengan dekonstruksinya tetap merawat ambiguitas dalam menjawab pertanyaan tersebut. Di satu sisi ia menolak jawaban final atas pertanyaan itu dengan alasan bahwa pencarian atas Hakikat manusia terkondisikan bersifat metafisika dan membatasi realisasi dari manusia itu sendiri. Di sisi lainnya, ia merengkuh semua jawaban atas pertanyaan tersebut karena manusia pada dirinya sendiri tetaplah sebuah realitas yang tidak dapat dipahami secara utuh selain melalui teks dalam bentuk ucapan atau tulisan. Dan teks itu sendiri tidak mampu untuk menjelaskan realitas secara utuh karena memiliki potensi untuk menghancurkan dirinya sendiri-bukan penghancuran yang berasal dari luar — untuk mendorong kemunculan teks yang-lain (oto-dekonstruksi).

Dengan demikian, Derrida kembali menekankan bahwa realitas pada dirinya sendiri tetaplah sebuah misteri yang tidak akan pernah terungkapkan (noumena) dan filsafat adalah jalan untuk menegaskan status quo tersebut. Dengan demikian, dalam konteks manusia, kita hanya dapat mengucapkan atau menuliskan tentang "Siapakah manusia" tanpa mencapai pemahaman yang penuh tentang manusia itu sendiri.

\section{Daftar Pustaka}

43 Jacques Derrida, Structure Event Context dalam Limited Inc., Penerj. Samuel Weber (Evanston: Northwestern University Press, 1988), hal. 7. 
Ariew, Roger; Chene, Dennis Des; Jesseph, Douglas M.; Schmaltz, Tad M.; Verbeek, Theo. 2015. Historical Dictionary of Descartes and Cartesian Philosophy. Lanham: Rowman \& Littlefield.

Audi, Robert. 1999. The Cambridge Dictionary of Philosophy: Second Edition. Cambridge: Cambridge University Press.

Caygill, Howard. 2009. A Kant Dictionary. Maden: Blackwell Publishing.

Copson, Andre. 2015. "What is Humanism?" dalam The Wiley Blackwell Handbook of Humanism. West Sussex: John Wiley \&Sons, Ltd.

Derrida, Jacques. 1982. Margins of Philosophy. Sussex: The Harvester Press Limited. , Jacques. 1997. Of Grammatology. Baltimore: The Johns Hopkins University Press. , Jacques. 1988. "Structure Event Context" dalam Limited Inc. Evanston: Northwestern University Press.

Descartes, René. 2003. "Discourse on the Method of Rightly Conducting the Reason." dalam Dover Philosophical Classics. New York: Dover Publications, Inc.

Feuerbach, Ludwig. 2008. The Essence of Christianity. Walnut: MSAC Philosophy Group.

Hegel, Georg Wilhelm Friedrich. 2012. "Philosophy of Mind" dalam The Encyclopedia of the Philosophical Sciences Volume 3: Hegel's Philosophy of Mind. Oxford: Clendon Press.

Inwood, Michael. 1999. The Blackwell Philosopher Dictionaries: A Heidegger Dictionary. Oxford: Blackwell Publishers Ltd.

Kant, Immanuel. 1998. Critique of Pure Reason. Cambridge: Cambridge University Press.

Kirk, Russell. 1956. "Introduction" dalam Oration on the Dignity of Man. Chicago: Henry Regnery Company.

Lawrence, Rachel V. Kohout. 2008. "Foreword" dalam The Essence of Christianity. Walnut: MSAC Philosophy Group.

Mirandola, Giovanni Pico Della. 1956. Oration on the Dignity of Man. Chicago: Henry Regnery Company.

Monsofani, John. 2000. "The Theology of Lorenzo Valla" dalam Humanism and Early Modern Philosophy. London dan New York: Routledge.

Moran, Dermot dan Joseph Cohen. 2021. The Husserl Dictionary. London: Continuum International Publishing Group. 
Sartre, Jean-Paul.1956. Being and Nothingness: An Essay on Phenomenological Ontology. New York: Philosophical Library. 